\title{
The Methodology of Strengthening Akhlakul Karimah and Model Worship Practice at Modern Dayah Yapena Lhokseumawe
}

\author{
Al Mawardi ${ }^{1}$, M. Iqbal ${ }^{2}$, Maulizar $^{3}$, Novi Quenta Rahayu ${ }^{4}$, Ismed Wijaya ${ }^{5}$ \\ ${ }^{1}$ Civil Engineering Department, State Polytechnic Lhokseumawe, Aceh-Indonesia \\ ${ }^{2}$ Electronica Departments, State Polytechnic Lhokseumawe, Aceh-Indonesia \\ ${ }^{3}$ Commerce Departments, State Polytechnic Lhokseumawe, Aceh-Indonesia \\ ${ }^{4}$ Electronica Departments, State Polytechnic Lhokseumawe, Aceh-Indonesia \\ ${ }^{5}$ Commerce Departments, State Polytechnic Lhokseumawe, Aceh-Indonesia \\ *Corresponding Author: ismed.did@gmail.com
}

\begin{abstract}
The Dayah modern Yapena is one of the favorite Islamic boarding schools in Lhokseumawe city. Even though there is an assumption that the education system still lacks emphasis on strengthening morals, and the model of worship practice that is applied is more nuanced to the Muhammadiyah tradition on the other hand, the public interest in including their children has increased. The students in this dayah are not only from the cities of Lhokseumawe, Bireuen and North Aceh, but also from the districts of Central Aceh, Bener Meriah, Gayo Luwes, Langsa, and Aceh Tamiang. In this case, the favorite designation should not be given and the number of registrants should decrease, but on the other hand the enthusiasts for this dayah far exceed other modern dayahs in Lhokseumawe. According to the author's assumption, the large public interest is not only because of its strategic location, but also because of the modernization of the education system in this modern dayah. Based on the background above, the question arises; How is the methodology of moral development and religious practice models in the modern dayah Yapena so that it has increased and made progress? To find out the answers to these questions, a qualitative study was conducted using observation, interview and questionnaire distribution techniques. Based on the results of the study, it was known the efforts to develop morality were carried out by exemplary methods, giving advice, accustoming students to discipline, and through giving strict sanctions for students who commit violations. The teachers in collaboration with the Dayah OSIS and the usroh guardians actively supervised the students so that they always participated in congregational prayers at the mosque, and apply the tradition of living cleanly in the dayah environment. The obstacles faced in the effort to develop morals were the existence of dayah teachers who did not provide good role models for their students, and there was still a lack of support from the santri guardians for various dayah policies. Based on the results of the research, it was also known that the model of worship practices in the modern Dayah Yapena did not emphasize one of the schools in Islam, but gave freedom to choose various sects which were considered correct. So that, could be stated that the negative assumptions of society as mentioned at the beginning of this paper were not true. The assumption of some community members and student guardians that the modern dayah Yapena adheres to the Muhammadiyyah sect was not proven.
\end{abstract}

Keywords: Methodology; education; akhlakul karimah; worship practice, Dayah Yapena

\section{INTRODUCTION}

\subsection{Background of Study \\ Dayah modern Yapena is one of the favorite dayah in the city of Lhokseumawe. This}

may be due to its strategic location, comfort, peace and beauty, compared to other modern dayahs in the city of Lhokseumawe. Based on the dayah public relations agency, it was stated that Damora enthusiasts had increased from year 
to year. This means that the people of Aceh still have great interest and consider this dayah to be superior, favorite and highly competitive, both in the fields of religion, language and general sciences. The amount of public interest in the dayah is inseparable from the foundation's solidarity with the madrasah and the modernization of dayah education management that is carried out consistently, optimally and optimally.

Even so, there are still some members of the community who have negative assumptions about this dayah. Based on the author's observations, it is known that some people in Lhokseumawe City think negatively about the model of cultivating moral values and the model of worship practice in the modern dayah Yapena. The community, and even some student guardians, complained about the character building model and the model of worship practices applied in the modern dayah Yapena. Some people even claim that the model of worship practice in Dayah tends to the Muhammadiyah tradition, because they never read the prayer qunut at every shubuh prayer in congregation, and do not read the prayer together after every fardhu prayer in congregation.

According to the author, this subjective assumption is certain because there is a basis and factual evidence which is difficult to justify objectively and scientifically. The public in general hopes that the model for cultivating morals and practices of worship should always be in accordance with the 'ahlu sunnah waljama'ah, which is a sect that is syariah based on the Qur'an, al Hadith, and the ijma' of the ulama. This is also because the people of Aceh in general not only expect their children to master high skills and knowledge but also have faith, aqidah and morals in accordance with the Ahlu Sunnah wal jama'ah.

With regard to the cultivation of moral values, it is also assumed that they are not good enough in the modern dayah Yapena. The negative issue regarding the lack of moral guidance in the Damora dayah emerged in midMay 2017, namely due to the arrogance of senior santri towards their juniors. On May 21, 2017, Kompas daily, Serambi Indonesia daily and several other social media exposed that there had been arbitrary actions by Yapena's senior santri of modern dayah to several junior santri. This arrogant and arbitrary action was acknowledged by the leader of Damora, Zainal Yaqob, and was subsequently resolved amicably by summoning the guardian of the santri concerned.

According to the author, the dark phenomenon that reflects moral degradation as happened in the dayah also often occurs in other dayahs. Furthermore, according to the writer's opinion, that the model of cultivating akhlakul karimah and the model of worship practice in the modern dayah of Arun is not a manifestation of a particular sect such as Muhammadiyah and NU, but a model of worship that reflects the two schools that lead to ahlu sunnah waljama'ah.

From the description above, it is known that on the one hand the modern dayah Yapena is considered to be one of the favorite dayahs, but on the other hand there is a negative perception of the model of moral cultivation and the practice of worship. Supposedly, if the model for cultivating the character of akhlakul karimah and the model of routine worship practices is still considered not in accordance with the teachings and cultural customs of the people in Aceh in general, there will be no improvement and progress for this institution. However, what happened was the opposite, namely the Yapena modern dayah was considered the favorite and prestigious dayah in the Lhokseumawe City area.

In this context, there seems to be something special about dayah Yapena, both in its teaching system, teaching infrastructure and facilities, as well as in the quality of its resources. To find out further, how the model of moral development and practice models of worship in the modern dayah Yapena, the authors conducted a qualitative research entitled "Methodological orientation of moral enhancement and models of worship practices in Modern Dayah Yapena Lhokseumawe"

\subsection{Problems of Research}

The problems studied include; methodology to improve morals and models of routine worship practices in the modern dayah Yapena. Based on this, the formulation of the research problem is; what is the methodology for building morals in Yapena's modern dayah?; and how is the routine model of worship practice implemented in the modern dayah Yapena? Based on this formulation, this research activity was carried out to determine 
the methodology of moral development, and to identify models of routine worship practices in the modern dayah Yapena. To achieve this goal, the authors conducted qualitative research by examining the methodology of improving morals and religious practice models in the modern dayah Yapena.

\subsection{Study of Literature \\ 1.3.1 The educational methodology of Akhlakul karimah}

Akhlakul karimah is the soul of Islamic education. In this case, achieving a perfect character is the main goal of education. Akhlakul karimah will not be realized without a coaching process or effort. Therefore, moral development really needs to be implemented in life, including in the process of teaching activities. [2] Moral education can be interpreted as a serious effort in order to shape children's morals, by using well-programmed educational and coaching facilities that are carried out intensively consistently and continuously. [3]

Thus, moral education is an effort to build or instill a praiseworthy character, which implicitly means building traits or behavior patterns based on positive morals, not negative or bad ones. Substantively, moral education consists of three behavioral performances, namely; moral knowing, moral feeling, and moral behavior. [1] In this regard, according to [1] moral education is a process of providing guidance in the development of heart training, mental development, physical development, as well as the development of human feelings and intentions.

\subsubsection{The approach and moral educational method}

Efforts to improve one's attitude and behavior to be pure, clean and in accordance with the whisper of conscience are often known as tazkiyatun nafsi. Tazkiyatun nafsi is an approach to cleansing the human soul that has been dirty from sins and mistakes that have been committed, namely mistakes in the inner meaning that come from the human heart, such as envy, envy, hasad, ria, arrogance, arrogance, shirk, and the like. [4] The development of akhlak karimah in the sense of purifying the soul is a very important issue in Islam, it is even one of the main goals of the Prophet Muhammmad Saw. [5] In the Qur'an, Allah says, meaning: "As
We have sent to you an Messenger among you who recites Our verses to you, and purifies (yourself), and teaches you the Holy Book and Al Hikmah (As Sunnah), and teach you what you do not know. "(Al Baqarah:151)

Various cleansing and cleansing oneself of all ugliness and elevating it to a high level of morality is an important task of the Messenger of Allah who was sent to carry out such a mission. Wudu is a technique in purifying the soul. Allah swt said: "In it there are people who want to clean themselves. And Allah loves those who are clean ". (At-Taubah: 108). Apart from ablution ', prayer is also a means of purifying oneself. Prayer functions to purify oneself and limbs from evil and evil deeds. The Word of Allah: "Surely praying prevents (actions) heinous and evil." (Al-Ankabut: 45).

Apart from praying and $d h i k r$, fasting is a means of purifying oneself [5]. In accordance with the word of Allah: "O you who believe, it is obligatory for you to fast as it was required of those before you so that you are pious". (AlBaqoroh: 183). Rasulullah Saw explained that fasting is one of the reasons for giving forgiveness, liberation from hell, and going to heaven. Fasting is a shield, medicine and fortress from lust. Because fasting can magnify the soul, oppress and imprison lust, so that the soul is truly bright and peaceful.

In Islam, the purpose of education is to educate character, therefore, education of character and morals is the soul of Islamic education. For this reason, as expressed by Fadhil Jamali, Muslims must be able to create an education system based on faith in Allah SWT, because only true faith is the basis of true education and guides people to explore the essence of studying the right knowledge and knowledge that is true. true guide the people towards righteous deeds.

\subsubsection{The Practice of regular worship}

Worship is one of the applicable elements in Islamic teachings as a manifestation of the faith and sincerity of a Muslim. [6] Because worship is a manipulation of faith, devotion and love for Allah SWT, it must be carried out in an orderly, solemn manner and in accordance with the Sunnah of the Prophet. [7] Orderly worship is meant that in the implementation of the practice of prayers, dzikir, and other worship must be regular, 
manners, (tuma'ninah), polite, polite and full of sincerity. [8]

In terminology, worship means obedience, submission or obedience to Allah SWT. [9] The practice of worship referred to in this study is the procedure for carrying out routine worship in the modern dayah of Arun Yapena Lhokseumawe. These routine services are like thaharah worship, circumcision practice in prayer and outside prayer, as well as prayer services 5 times a day and night, individually or in congregation which are routinely carried out by dayah residents on a daily basis.

As usual, prayers five times a day and a night are always held in congregation at the mosque or dayah mosque. In various dayah institutions, congregational prayer is usually carried out in an orderly manner, starting with the rawatib qabliyyah sunnat prayer, and ending with the sunnat ba'diyyah prayer along with dhikr, sholawat and prayer 'in congregation including reciting qunut at the Fajr prayer in congregation. In Islam, there are two models of worship, namely mahdhah and ghairu mahdah. Worship mahdah is an activity or action that has been determined by the terms and conditions of the Prophet. [10] It means that the requirements are things that need to be fulfilled before an activity of worship is carried out. Based on the semantics of a hadith, practices of worship that are not in accordance with the example of the Prophet will be rejected, illegitimate or not accepted at all. [10] Therefore, the practice of worship must be sincere and mutaba'ah, following the example of the Prophet.

Thaharah and prayer are among the mahdah worship, namely worship that must follow the example of the Prophet. If you don't follow the example, the prophet said which means, "whoever does a practice that is not in accordance with our example, he is rejected." The meaning of this hadith shows that if a person does charity not as exemplified by the Prophet, then that charity is rejected. However, if only part of the deeds of worship are not appropriate, then the worship is accepted, but some parts of it are not. Something that is not exemplified is rejected even though the prayer as a whole is not rejected.

Just as there are those who perform prayers with bid'ah in it, so not all prayers are rejected, but bid'ah are carried out. In the realm of fiqh, there are many models of practical worship, namely; Thoharah worship (wudu ', tayamum, istinja', janabah bath), prayer services (fardhu 'ain prayer, fardhu kifayah, congregational prayer' and qasr, Friday prayers, and sunnat prayers), fasting, pilgrimage, and zakat. [10] However, this discussion only focuses on routine worship, namely thaharah (wudhu ') and prayer as worship which is always carried out in the modern dayah Yapena.

\subsubsection{Preliminary Study}

So far there have been several research results on moral development. Refernsi [11] once made a study which showed that moral education is absolutely necessary, especially in the era of globalization. According to [11] through strengthening moral development, a person will be able to face various modern problems, be it social, emotional, intellectual, or even spiritual problems. On the other hand, [12] also conducted a study entitled Efforts to increase honesty in religious education institutions towards a corruption-free Indonesia. Based on his research, he concluded that the issue of moral education is a priority in overcoming corrupt behavior.

Furthermore, [13] has also conducted research on the implementation of Akhlakul Karimah for students at the Simaliyah Islamic Boarding School, Kampar Regency. Based on the results of his research, it was concluded that the implementation of akhlakul karimah is very important to improve the learning quality of the students. A number of previous research results as mentioned above emphasize the existence and urgency of moral education, while this research focuses on the methodology of character building. Furthermore, [14] once examined the actualization of moral values in traditional dayah in Bireuen Regency, but the focus of his study was only limited to the problem of traditional dayah, whereas this study was aimed at integrated or modern dayah.

\section{RESEARCH METHOD}

\subsection{The Aproaches on Rsearch}

This research is qualitative research that emphasizes the search for information regarding the model of moral character development and the practice of worship in the modern dayah Yapena. This research is not intended to test the hypothesis; therefore it does not apply quantitative statistical calculation methods.[15] All information relating to the purpose of the 
research is then collected, organized, studied, interpreted and concluded into a unified whole concept. [16] The population of this study were dayah educational institutions and Yapena modern dayah residents. Due to the large number of population, the research sample was determined, in which case the purposive sampling technique was applied. Purposive sampling is a sampling technique for a specific purpose, namely that the selected sample is a person who is an expert in a field related to the research topic. [17] Based on these techniques, the samples of this study were foundation leaders, dayah leaders, madrasah heads, curriculum heads, head of care, and the dayah teachers.

\subsection{Research instrument}

The main research data were collected using observation, interview and questionnaire distribution techniques. Observation is the activity of searching for research data by actively observing attitudes and behavior, appearances, actions or activities that are intentionally or not, as well as things done by dayah residents, especially with regard to the model of character building and practice of worship in the modern dayah Yapena. . Interviews were conducted with informants, including; dayah leaders, foundation leaders, school principals, academic leaders, and head of care for male and female students.

Before conducting the interview, a list of interview questions was prepared based on the formulation and main research objectives.[18] Meanwhile, distributing questionnaires was used to collect information from dayah teachers. Literature data is categorized as secondary data. Secondary data obtained through literature studies, namely; from journals related to the topic of research, from articles, from books on morals, and from relevant research results.

\section{RESULT AND ANALYSIS}

\subsection{Result}

\subsubsection{Observation result}

Based on the observation results of the research activity implementation team, it was known that there were still some students who did not follow dayah rules such as those related to the Covid-19 health protocol, namely not wearing masks, did not care of social distancing. In the case of routine worship, namely congregational prayer, the students were around
$5 \%$, who often came late to the musholla. After the completion of the routine prayers in congregation, the students did not read dzikir and prayers together, especially during the dzhuhur prayer in congregation. While other sunnah practices were still being carried out, namely carrying out the sunnat qabliyyah prayer and dzuhur bakdiyyah. With regard to efforts to develop morals through the process of learning activities, it was based on the author's observation that dayah teachers had tried their best by providing routine advice on every teaching activity, even though the material taught was general field material.

Dayah teachers always provided examples such as always being present on time, well dressed, and polite and friendly in interacting with students. Based on the author's observations, the average student was always active and orderly in participating in teaching activities. Students carried out learning using various methods, such as the group discussion method, question and answer, completion of assignments, and actively listening to teachers' explanations. Of the many classes observed that looked rather naughty were only at the first grade of MTs, where the teacher was explaining they were still people who were fighting and were seen climbing the desk.

\subsubsection{The result of interview}

The results of the interviews by the research activity implementing team with figures and policy holders at the Modern Dayah regarding efforts to build morals are as follows. According to Ustadz Mulyadi, the head of children's care, akhlakul karimah development was very important and was in the first rank of all sciences. According to him this was in accordance with the hadith which means that "adab is above all knowledge." The model of moral development in the modern dayah was carried out by active coaching through the behavior and actions of dayah residents. The teachers set a good example and at the same time actively rebuked the despicable behavior of the students. With regard to the issue of worship practices, according to Ustazd Mulyadi, the practice of the implementation of worship in the modern dayah was more similar and tends to follow the Muhammadiyah sect.

Then, according to Mr. Zainal Yaqob, one of the leaders of the Yapena foundation, akhlakul karimah development was very 
important in life. In fact, according to him, Rasulullah Saw was sent to the world to perfect human morals. The model of moral development in Yapena's modern dayah was a combination of religious education and general education. The approach commonly used in the effort to improve morals was through the exemplary method. Dayah teachers must provide good examples and role models for their students. Teachers must always be disciplined, clean and tidy so that their students will follow. The obstacle faced in developing morals was that there were still educators in the modern dayah who had not been able to become role models for their students.

Regarding the model of worship practice, Zainal Yaqob stated that in Modern Dayah Yapena did not really limit the model of worship whether to follow NU or Muhammadiyah. The issue of worship practice, whether to use qunut at prayer shubuh or not was a matter of furu'iyyah, and was not too concerned with in this religion boarding school. Furthermore, according to Bakhtiar, MBA, one of the Directors of Dayah education, akhlakul karimah development was the mother of all knowledge. According to the hadith of the Prophet Muhammad which reads: "Al adabu fauqal ilmi". According to this hadith, before studying other materials, first studying morals material, especially in dayah institutions, efforts to build morals were the center of dayah's goals and visions.

Akhlakul karimah development in modern dayah Yapena was carried out by integrating character-oriented subjects, which was four hours a week in the classroom, then accompanied by in-depth guidance by dayah caregivers. Problems or obstacles in the development of akhlakul karimah arose because students had individual differences. According to him, the santri in Yapena's modern dayah had different abilities and dispositions based on congenital, educational background or family.

In this case, it required strict discipline and order. The students were obliged to be disciplined to comply with the rules of the dayah, so that if someone commits a serious violation, they should be given sanctions to be expelled from the dayah. One model of discipline that students must follow was that they were obliged to participate in regular congregational prayers five times a day and a night. Students who did not participate in five consecutive times or pray in congregation would be expelled from the baitul hufadz group. In addition, there was regular guidance and coaching for santri who commit violations.

It was the same with Zainal that regarding the model of worship practices of the santriwan and santriwati, there was no distinction between the practice of worship according to NU or according to Muhammadiyah. According to him, the main and important issue of worship is that the worship was appropriate and follows the salafus salafus whose truth was guaranteed. Furthermore, according to the chairman of Takhfidz class, Ridha, Lc, the process of fostering and enhancing the akhlakul karimah was highly prioritized in the Yapena, because today's young generation who would become leaders in the future will be destroyed if they only had knowledge but did not have akhlakul karimah. The process of developing students' morals had been carried out since the selection process for the admission of new students, where only students who had good moral and talented were accepted as dayah people. Problems and difficulties in akhlakul karimah development arose more frequently in the eight grade students, namely students who had transferred from other schools. The transfer students who had problems at their original school often influenced other santri to behave in a disgraceful manner. The solution taken was to carry out a strict selection, especially when continued to the senior Islamic high school level.

In the field of worship, the modern dayah Yapena focused on the Qur'an and the Sunnah of the Prophet, not on fiqh mazhab or furui'yyah. According to Ustadz Ridha, dayah thrutly gave freedom to the students or teachers to choose whether to worship according to the NU or Muhamadiyah sect. According to him, dayah students and teachers were always given freedom in carrying out the practice of worship whether to read qunut or not (at Fajr prayers), and whether to follow or commemorate the Prophet's mauled or not.

Furthermore, according to the Head of senior Islamic high school of Yapena, efforted to develop morals were carried out by conveying good and bad understanding to students. Students were expected to be able to understand the meaning, advantages and disadvantages of good and despicable traits or 
behavior and were expected to be able to choose it as a path or guide in everyday life. Then through habituation to good behavior in everyday life, both at home, at school, and in other environments. Efforted to develop or strengthen morals were carried out with assistance, namely by the homeroom teacher and wali usroh. If the homeroom teacher tried to foster, encourage and accompany students intensively when they were at school, then the wali usroh tried to assist the students by supervising, advising, and even giving warnings or sanctions when the students had returned to the dormitory or outside academic school hours.

The approach taken in strengthening the values of akhlakul karimah was through habitual behavior such as; always say greetings, read basmalah, respect and love each other, and discipline in following the rules of the dayah. The main books that must be studied in the field of morals were; Ta'lim Muta'alim book and Marratil Ubudiyyah book. In the Ta'lim Muta'lim book, matters relating to morals were presented, such as; morals towards teachers, parents, friends, neighbors, leaders, and others. Whereas in the book Marratil Ubudiyyah, it was presented with matters relating to daily Sunnah practices, and prohibitions that need to be avoided in order to become a noble human being. Another approach in the effort to strengthen morals was by studying adab and prayer materials, and by empowering mentoring by homeroom teachers and wali usroh.

The method of moral education that was often used was modeling and giving advice to students. In the effort to develop morals, there were several obstacles faced, namely; the magnitude of the influence of social media through information technology. Another obstacle was the lack of support from student guardiant, especially when dayahs apply strict discipline for the advancement and improvement of the quality of education. According to the head of the MA Yapena, the policy that needed to be implemented to overcome these obstacles was to prohibit students from using cellphones and similar technology tools such as computers or laptops, except when students were already in last class in the second semester. Another policy was to streamline communication with walisantri, so as to provide moral and spiritual support to the dayah in improving the quality and morals of the students.
On the other hand, according to Muhammad Rizal, as the head of junior Islamic high school, the effort made in building akhlakul karimah was to improve one's own morality or morality first. Teachers must improve their attitudes and behavior so that they were better and had noble character. Further more the techers were able to provide good examples to their students. In this case, an important strategy to implement was the example of the teaching staff and education implementers. In addition, it was necessary to empower homeroom teachers, wali usroh and counseling teachers. The homeroom teacher must provide in-depth guidance to his or her children so that they were more empowered and had noble character. The wali usroh must also actively supervise and foster the students so that they always behad well and honorably while in the dayah environment. Meanwhile, the Counseling Guidance (BK) was also empowered to always be active in carrying out its duties, namely motivating, directing and solving all problems faced by the students, especially those related to morals and psychological turmoil.

The difficulty faced in the development of akhlakul karimah lied in the large number of students compared to the number of teachers. According to M. Rizal, teachers had limited time in providing guidance effectively and thoroughly to the large number of students. This was because the teachers also had quite a lot of main tasks, both as teachers and as parents to their children in their respective families. Another obstacle was the lack of support from the santri guardians. The guardians of santri too often complained and criticized the dayah policy, even though the policies implemented aim to improve the quality, quality of education and strengthen the morality of the santri. According to the head of MTs, the solution applied was to communicate openly with the santri guardians, namely explaining the objectives and logical reasons for all the policies implemented. Another solution was to empower the main duties and functions of the homeroom teacher, wali usroh and counseling teachers in the modern dayah Yapena.

\section{1,3 The result of questionnaire}

The results of research on efforts to develop akhlakul karimah in the Modern dayah Yapena obtained through questionnaires 
could be seen at the table 1, 2, and 3 were as

follows:

Table 1. The Approach of Strengthening Akhlakul Karimah

\begin{tabular}{|c|l|c|c|c|c|}
\hline \multirow{2}{*}{ No } & \multicolumn{2}{|}{ The approaches of teaching } & \multicolumn{4}{c|}{ Alternative } \\
\cline { 3 - 6 } & & $\begin{array}{c}\text { Very } \\
\text { agree }\end{array}$ & Agree & Disagree & $\begin{array}{c}\text { Very } \\
\text { disagree }\end{array}$ \\
\hline 1 & Seting the lessons such as: PKn, ta'bir, adab and do'a & 15 & 10 & 2 & - \\
\hline 2 & Througth role mode/ method & 16 & 10 & 1 & - \\
\hline 3 & Used to be discipline habituation method & 15 & 10 & 2 & - \\
\hline 4 & Advice or tausiah method & 12 & 14 & 1 & - \\
\hline 5 & Contructive punishment method & 11 & 14 & 2 & - \\
\hline & Average & 13,8 & 11,6 & 1,6 & - \\
\hline & Percentage & $51,11 \%$ & $42,97 \%$ & $5,92 \%$ & - \\
\hline
\end{tabular}

Table 2. The Difficulties in Strengthening Akhlakul Karimah

\begin{tabular}{|c|c|c|c|c|c|}
\hline \multirow{2}{*}{ NO } & \multirow{2}{*}{ The difficulties faced } & \multicolumn{4}{c|}{ Alternative } \\
\cline { 3 - 6 } & & $\begin{array}{c}\text { Very } \\
\text { agree }\end{array}$ & Agree & Disagree & $\begin{array}{c}\text { Very } \\
\text { disagree }\end{array}$ \\
\hline 1 & Less of good role mode/ from Dayah teachers & 7 & 15 & 5 & - \\
\hline 2 & Internal factor of students (individual differences) & 12 & 11 & 4 & - \\
\hline 3 & Less of support from students guardian & 11 & 14 & 2 & - \\
\hline 4 & The influence of social media's environment & 10 & 15 & 2 & - \\
\hline & Average & 10 & 13,75 & 3,25 & - \\
\hline & Percentage & $37 \%$ & $50,92 \%$ & $12 \%$ & - \\
\hline
\end{tabular}

Table 3. The Model of Practice worship at Dayah Yapena

\begin{tabular}{|c|c|c|c|c|c|}
\hline \multirow[b]{2}{*}{ NO } & \multirow[b]{2}{*}{ Model of practical worship } & \multicolumn{4}{|c|}{ Alternative } \\
\hline & & $\begin{array}{c}\text { Very } \\
\text { agree }\end{array}$ & Agree & Disagree & $\begin{array}{c}\text { Very } \\
\text { disagree }\end{array}$ \\
\hline 1 & Sanri never read dzikir, wirid, and prayer together & 4 & 11 & 10 & 2 \\
\hline 2 & Santri rarely read qunut at prayer Shubuh together & 6 & 8 & 10 & 3 \\
\hline 3 & $\begin{array}{l}\text { The practice of Santri's worship tended to } \\
\text { Muhammadiyah }\end{array}$ & 4 & 12 & 11 & - \\
\hline & Average & 4,66 & 10,33 & 10,33 & 1,66 \\
\hline & Percentage & $17,25 \%$ & $38,26 \%$ & $38,26 \%$ & $6,14 \%$ \\
\hline
\end{tabular}

\subsection{Discussion and Analysis}

Based on the results of research through observations and interviews as noted above, it was known that the Yapena Modern Dayah had implemented a number of policies to improve morals. Through the author's observations, it was evident that the dayah leaders had issued written regulations so that dayah teachers were always active, disciplined, and carried out their duties professionally and proportionally. This means that dayah teachers were required to carry out their duties and functions properly and responsibly. Dayah teachers were required 
to be good role models and taught a number of their knowledge and experiences in a varied, fun, and oriented way to develop students' talents and interests. On the other hand, based on the author's observations, it was evident that dayah teachers were always active and enjoy their duties as educational staff. Likewise, the students looked harmonious, respect each other, love; help each other, and value time. This proves that Yapena's modern dayah residents had morals and a passion for learning. Indeed, there were still some students who behaved despicably and violated the rules of the dayah, but only a minority of the dayah residents.

Furthermore, from the results of the interview, it was also known that dayah leaders and teachers had made efforts to strengthen the morals and morals of the students. Dayah leaders and teachers agreed that the issue of morality was a priority issue in dayah institutions. A number of other lessons were secondary material needed for the necessities of life in the world. Meanwhile, morality subject matter was the primary material that must be studied and applied in everyday life. In this case, as stated by Hamdun Fadhil, the head of MA Yapena, the books that must be taught and mastered by dayah teachers were Ta'lim Muta'alim and Marratil Ubudiyyah. The dayah teachers were obliged to teach both of us after sunset, Isya and Fajr prayers in congregation.

With regard to the practice model of worship, Yapena's dayah leaders and teachers agreed not to force dayah residents to follow one of the streams in Islam, instead giving freedom to believe based on the knowledge they had as long as that flow was in accordance with the guidance of 'ahlussunnah waljama'ah. This was as conveyed by Ustadh Ridha and Zainal Yaqob, where the modern dayah Yapena did not question the problem of furu'iyyah in Islam, but focused on improving the quality of education so that it was able to face global challenges. From the author's observations, it was true that students never read prayers and qunut after the Fajr prayer in congregation, but personally it was likely that they would still read them consistently. From these findings it was evident that the negative assumptions of society as mentioned at the beginning of this paper were not true. The assumption of some community members and student guardians that the modern dayah Yapena adheres to the Muhammadiyyah sect was not proven.
Furthermore based on the table 1 above, it was known that efforts to develop akhlakul karimah were more effective through exemplary methods. From the above table, it could be seen that of the 27 research respondents, 16 people (59\%) of whom chose the 'item' strongly agreed 'on the use of exemplary methods, and 15 people $(55 \%)$ chose the method of' habituating good behavior 'in an effort to build character akhlakul karimah. Meanwhile, other methods such as giving advice and imposing sanctions / punishments were only selected for the item "strongly agree" by 11 people (42\%) of the 27 respondents. Meanwhile, based on table 5.1 above, it could also be stated that of the total research respondents, $51.11 \%$ of them felt strongly agreed, and $42.97 \%$ chose the item 'agree' with the use of exemplary methods, habituation, giving advice and determining punishment in an effort to improve morals. Meanwhile, only $5.92 \%$ of the total respondents chose the item of 'disagree'.

Then, based on the table 2 above, it was known that the obstacles or difficulties faced in efforts to improve morals in the Modern Yapena dayah lie in the innate factors of students, the lack of support from santri guardians, the influence of social media, and the lack of exemplary education personnel. This was evident, where out of 27 dayah teachers who were research respondents, 10 $(37 \%)$ of whom chose the item "strongly agree" and 14 people $(51 \%)$ among them chose the item "agreed". Meanwhile, only 3 people (12\%) of the total respondents chose the item "disagree". Finally, based on the table 3 above, it could be seen that the model of routine worship practices commonly carried out by santri and education personnel in the modern dayah Yapena was not limited to the Muhammadiyyah or NU sect. This was proven, where from the total research respondents, $38.26 \%$ chose between the item "agree" and the item "disagree". Meanwhile, those who chose the item "strongly agree" that the religious practice model in the Yapena dayah tended to the Muhammadiyah sect only $17.25 \%$, and those who chose the item "strongly disagree" amounted to $6.14 \%$.

In this case it could be concluded that of the total respondents, only $10 \%$ of them admit that the model of worship practice in the modern dayah Yapena tends to be 
Muhammadiyah. This was as conveyed by the head of MTs and MA Dayah modern Yapena, where the students were always nurtured and motivated to channel their talents and interests through the empowerment of dayah education extracurricular activities. Syarif Al Farisyi, a senior santri and board member of OSIS, also mentioned that the students actively participated in extra-curricular activities. Through this activity, talented santri were nurtured, encouraged and directed in a sustainable manner, so that when there was an event or competition, the students always got brilliant achievements at the local, regional and even provincial levels.

\section{CONCLUSION}

Based on the results of the previously written research, it could be concluded to several things, namely: First, that Dayah Modern Yapena had tried to improve the morals of the students with various teaching techniques, such as through exemplary methods, habituation methods, giving advice or tausiah. and giving sanctions for students who violate rules or the regulations of dayah. This was in accordance with what was conveyed by the heads of madrasah and foundation leaders that efforts to develop morals were a priority agenda at the Yapena. This statement was also in accordance with the author's observations, where at the time of teaching activities, dayah teachers were seen to be good role models for their students. The students were active and participate in learning activities in an orderly, active, and fun way.

Second, based on the results of interviews with Modern Yapena dayah leaders, it was known that several obstacles were faced in efforts to develop morals, namely internal and external obstacles. The internal factor was that there were still dayah teachers who did not provide good role models for their students so that they were distracting in enforcing dayah discipline. Meanwhile, the external obstacle was that there were still santri guardians who were not providing support for dayah policies. In addition, due to the different backgrounds of the students, some came from good schools and some came from poor schools. Third, the model of routine worship practices in the modern dayah Yapena did not tend to follow one sect. Yapena's modern dayah institutions and foundations gave dayah students and teachers the freedom to follow one of the schools of Islam, as long as it was in accordance with the Sunnah of the Prophet. Fourth, from the result of research it was evident that the negative assumptions of society as mentioned at the beginning of this paper were not true. The assumption of some community members and student guardians that the modern dayah Yapena adheres to the Muhammadiyyah sect was not proven.

\section{REFERENCES}

[1] Rosihan Anwar, Akidah Akhlak, Bandung: Pustaka Setia. 2011

[2] Muniral, "Akhlak dalam Perspektif Pendidikan Islam," Auladina, Jurnal Pendidikan Dasar, Vol. 4, No. 2, Tahun 2017, Makasar: UIN Alauddin, ISSN: 2407-2451

[3] Iwan, "Pendidikan Akhlak Terpuji Mempersiapkan Generasi Muda Berkarakter" Jurnal Al Tarbawi Al Haditsah, Vol. 1, No. 1. 2017. ISSN: 2407-6805. IAIN Syeikh Nurjati, Cirebon

[4] Abu Hamid Muhammad al Ghazali, Ihya Ulum ad Din, Jilid III, hal. 58, Beirut: Dar al Fikr. 1989

[5] Said Hawwa, Tazkiyatun Nafsi, Jakarta: Gema Insani Press. 2007

[6] Hasbi Ash Shieddieqy, Kuliah Ibadah: Ibadah Ditinjau dari Segi Hukum dan Hikmah, Semarang: Pustaka Riski Putra. 2010

[7] Moh. Rifa'i, Ilmu Fiqih Islam Lengkap, Jakarta: Toha Putra. 2010

[8] Mawardi Labay El Sul Thani, Mendirikan Shalat yang Khusyuk: Mencegah Manusia dari Perbuatan Keji dan Mungkar, Jakarta: Mawardi Prima. 2011

[9] Mahmud Ahmad Mustafa, Tuntunan Shalat Wajib Lengkap, Yogyakarta: Mutiara Media. 2008

[10] Abu Bakr Jabir Al Jazairi, Ensiklopedi Muslim: Minhajul Muslim, Jakarta: Darul Falah. 2000 
[11] Masnur Muchlis, 2011, Pendidikan Karakter, Jakarta: Gramedia

[12] Rokhimah, 2012, Proses Pembinaan Karakter Generasi Muda, Bandung: Mizan

[13] Marinah, 2015, "Implementasi Akhlakul Karimah" Thesis, Makasar, tp

[14] Iqbal, 2017, "Aktualisasi nilai-nilai akhlak pada dayah tradisional di Kabupaten Bireuen", Skripsi, Aceh: Unmus

[15] Sutrisno, Penelitian Kualitatif, Jakarta: Gramedia. 2004

[16] Nadjir, Metode Penelitian, Banda Aceh: LPPM Syi'ah Kuala. 2003

[17] Suharsimi Arikunto, Evaluasi Pendidikan, Jakarta: Gramedia, hal. 56, 2008

[18] Moloeng, Metode Penelitian Pendidikan, Jakarta: Rajagrafindo Persada. 2007 